ISSN: $2651-401 \mathrm{X}$

\title{
Bioengineering Methods in the Production, Development and Metabolism of Essential Oil in Plants
}

\section{Özlem Karaboyacı ${ }^{1 *}$, Semra Kılıç²}

\begin{abstract}
Essential oils are odorous oily liquids derived from plant material. Essential oils have been used extensively from pre-history times as, bactericidal, fungicide, insecticidal, and medical purposes. Many of these components are produced as secondary metabolites in plants. Therefore, the development of production of these components are important in terms of medicine and industry. In this study, bioengineering methods used in the production, development and metabolism of essential oils in plants were investigated. Recent developments on this issue have been summarized and reported.
\end{abstract}

Keywords: Essential oils, bioengineering, seconder metabolites

\section{Introduction}

People use plants to obtain an important portion of the essential foods they need to survive. Plants are a crucial source of nutrients such as carbohydrates, protein, fat, minerals and vitamins. They also contain highly important chemicals for pharmaceutical, chemical, cosmetic and agricultural control industries. These chemicals are referred to as "secondary metabolites" and some plant products are considered under this category. High diversity in the number and structure of secondary metabolites is a specific characteristic of secondary metabolites. They are understood to have a very complicated mechanism specific to plants for defence, protection, adaptation, survival and continuation of next generations. The available written historical sources mention that ancient humans used plants for the treatment of various diseases. It is doubtless that this type of usage was not based on the secondary products that are active substances but on the plant itself or its extracts obtained through different means. Today, plants are used as pharmaceutical active ingredients. Medical and aromatic plants are those ones that are used to prevent diseases, maintain health or treat diseases. Medicinal plants are used in nutrition, cosmetics, body care, incense or religious ceremonies while aromatic plants are used for good smell and taste (Bayram et al., 2010).

Essential oils are mixtures that are extracted from plant roots, bodies, leaves, fruits, barks and flowers by different methods; are in liquid form at room temperature, volatile with a strong scent, can be easily crystalized, are usually colourless or light yellow, give the plant its characteristic smell and flavour, contain several compounds, have lipoid structure that can be drifted with water, contain oxygenated terpenoit derivatives, benzoid compounds, nitrogen or sulphur and are usually comprised of terpens (Adams, 2004; Bayrak, 2006; Çalikoğlu et al., 2006;, Evren and Tekgüler 2011;, Yayl1, 2013; Kaya and Ergönül 2015). They exist in the glandular hair, secretion pocket, secretory canals or secretory cells depending on the family of the relevant plant (Çelik and Çelik, 2007).

${ }^{1}$ Suleyman Demirel University, Faculty of Engineering Bioengineering Dpt. 32260, Isparta, TURKEY

${ }^{2}$ Suleyman Demirel University, Faculty of Arts and Science, Biology Dpt. 32260, Isparta, TURKEY

*Correspondingauthor: ozlemkaraboyaci@gmail.com
Citation (Atıf): Karaboyacı, Ö., Kılıç, S., (2018). Bioengineering Methods in the Production, Development and Metabolism of Essential Oil in Plants. Bilge International Journal of Science and Technology Research, 1-9. 


\subsection{What is Essential Oil?}

Essential oil is a natural, usually colourless or light yellow product with a strong scent that is obtained from plant leaves, fruits, barks or roots, is in liquid form at room temperature and can be easily crystalized.

It is also referred to as essence or etheric oil because of its nice scent. It does not mix with water, which makes it different from the fatty oil although it is defined as oil (Ceylan, 1983). Essential oils in plants are obtained by various methods Once their components have been identified, than their use can be determined. Generally, in order to determine the amount of this essential oil in the plants, certain parts must be subjected to distillation with green or dried. After this process, the determination of volatile oil compositions is made by methods such as GC and GCMS (Gülsoy and Merdin, 2017).

\subsubsection{Chemical Characteristics of Essential Oils}

Terpenes constitute the largest group in the chemical structure of essential oils. Some compounds also contain low amount of alcohols, aldehydes, esters, phenols, nitrogen and sulphur. The oxygenated derivatives that are formed due to the oxidation of terpenes give plants their scent and flavour while they are also therapeutic (Linskens, 1997).

\subsubsection{Pharmacological Properties of Essential Oils}

The activity of an essential oil is confused with the action of the plant from which it is extracted. For example, the essential oil of Rosmarinus is antimicrobial while the infusion of the plant has an antispasmodic and choleretic effect.

The activities found in some essential oils are as follows;

Antiseptic activity: They are often antiseptic against strains that are resistant to antibiotics. Some essential oils are also effective against fungi and yeasts. Almost all of them are used as preservative. Melisa officinalis, Rosamarinus officinalis, Mentha piperita, Lavandula, Eucalyptus, Eugenia... vs. Sitral, Geraniol, Linalol and Timol are more antiseptic than phenols.

Spasmolytic and sedative effect: They reduce and suppress GIS (gastro intestinal system) spasms. They often increase gastric secretion and have "digestive" and "stomachic" effect. They are effective in various psychosomatic problems. Thymus, Ocimum, Angelica, Matricaria, Eugenia, Melisa, Mentha are spasmolytic. O.Anisi is used internally as spasmolytic. O. Menthae shows spasmolytic effect by preventing calcium entry into cells .

Irritant properties: Products such as turpentine increase blood flow in capillary vessels, local rash, sense of burn and show slightly local anaesthetic effect in some cases if used externally. Oils such as Eucalyptus, Pinus and O.Niaouli stimulate the cells in the mucosa and increase the mobility of the epithelium of the bronchi (expectorant). Essential oils that are used in various sectors such as cosmetic, perfumery, pharmacology and food industries have been extracted by different methods since the Romans.

Essential oils are used as spasmolytic, irritant, antiseptic, antimicrobial, antifungal, antiviral, antimutagenic and antibiotic agents in the pharmacology (Evren and Tekgüler, 2011).

\section{Bioengineering Methods for Essential Oil Production and Metabolism}

Increased industrial interest in plant-based chemicals has also been increasing the attention to the plants' secondary metabolisms and the physiology and biochemistry of plant products. it is important to change the phytochemical production positively through conventional and non-conventional biotechnological methods. Most of the plants' secondary metabolites (SM) depend directly and indirectly on the plants' reactions to various environmental factors and stimuli. They are usually produced at baseline level in their normal course that is triggered by cell damage or as a reaction to external factors, and function as phytopharmaceuticals. Secondary metabolites are usually produced in their normal course. They are triggered in case of cell damage or as a reaction to external factors and start functioning as phytopharmaceuticals. Moreover, bioactive compounds are used widely directly in cosmetics, aroma and perfumery industries, as paint and pigment, 
food additives, insecticides or as an important component in various formulations. The use of plant-based bioactive compounds in modern medicine has successfully focused the global attention on the research of medicinal plants at global level. The need for plant-based therapeutic molecules in the pharmaceutical industries across the world has increased. The main ways of obtaining such components include extraction from natural resources and chemical synthesis. Non-environmental friendly nature of conventional extraction method that is non-renewable, uneconomical and time-consuming has increased the interest of global scientific community in the biotechnology-based production systems (Dubey et al. 2017).

\subsection{Plant Tissue Culture}

It refers to the process of obtaining new tissues, plant or plant products (such as metabolites) from the whole plant, plant parts such as cells (meristematic cells, cell concentration or callus cells), tissues or organs (apical meristem, root etc.) under aseptic conditions (in an environment free from any kind of microorganisms) in an in vitro medium. The main objectives of tissue culture are to develop a new variety and create genetic diversity in the existing varieties. Furthermore, various tissue culture methods are routinely used to save and endangered species and production of species that are difficult to propagate (Babaoğlu et al. 2001).

\subsection{Secondary Metabolites}

They are produced by a very complicated mechanism that plants develop for defence, protection, adaptation, survival and continuation of next generations. Secondary metabolites have important functions such as resistance to various abiotic agents such as drought, salinity, UV beams; defence against herbivores and microorganisms; attracting animals and other carriers for pollination and seed distribution. Moreover, they also have an economic value. For example; they are used as pharmaceutical ingredients, food supplements and in perfumes and agricultural control products. Since they are important not only for plants' defence against pathogens but also in economic and medical aspects, plant tissue culture techniques have become one of the most important means for their production. (Atar and Çölgeçen 2013)

Plants are used as pharmaceutical active ingredients for most of the world population. Particularly in the developing countries, $80 \%$ of the population meet their health requirements primarily through medicinal products. Given that $80 \%$ of the world population live in the developing countries, $64 \%$ of the total world population use plants for therapeutic purposes. In the developed countries, however, $25 \%$ of the prescribed drugs are plant-based chemicals. There is no doubt that the exploration and assessment of plants used by people for the treatment of various diseases, which are named as folk remedy, have played an important role in their discovery (Babaoğlu et al. 2001).

Today, secondary metabolites have a huge potential for use. There are some challenges and disadvantages in extracting them from plants under natural conditions. Plants are raised in small quantities and at certain development stages under natural conditions, during which they occupy agricultural fields; constant collection of some plant species from the nature may pose extinction threat, while it is difficult and expensive to collect some of them. Furthermore, the amount and quality of secondary metabolites are influenced by the climate conditions. They can be produced in desired quantities at the desired time through biotechnological means, extinction danger is also eliminated, while they can be produced in abundant amounts at standard quality.

There are basically 3 systems to produce secondary metabolites through plant cell and tissue culture, which can be summarized as follows.

\subsubsection{Metabolite Production through Differentiated and Organized Cultures}

Root Cultures: With this method, in cases where metabolites are synthesized in the root, the parts taken from it are cultured in an appropriate medium. Moreover, adventive root cultures (root formed in another organ of a plant apart from its normal root growth region) that are obtained by stimulating different tissues of the plant (laves, body, nodes etc.) for root growth are preferred to produce secondary metabolites from some plants (Erkoyuncu and Yorgancilar 2016). 


\subsubsection{Metabolite Production through Non-Differentiated and Non-Organized Cultures}

Callus is a stack of differentiated cells formed by plant cells or tissues placed in in vitro culture media. Callus is usually formed on the surfaces of injured or cut tissues (Babaoğlu et al. 2001). Callus cultures can be described as masses with morphological irregularities formed by in vitro culturing of organs or tissue pieces excised from the main plant that still retain their mitotic capabilities. The origin of the tissue where callus culture is initiated plays an important role for the production of secondary metabolites (Erkoyuncu and Yorgancilar 2016.).

\subsubsection{Micro Propagation Method}

Micro propagation is a tissue culture technique used to propagate high number of genetically similar plants quickly from the plant parts (embryo, seed, body, shoot etc.) that have the potential to form a whole plant in the in vitro media under microorganism-free conditions (Özkaynak and Samanc1 2005).

Micro propagation also enables the vegetative propagation of several medicinal and aromatic plants fast and in high quantities. If the nutrient requirements of plants, growth regulator and culture requirements are known very well, all plant species can be produced using the micro propagation technique. The micro propagation of medicinal and aromatic plants has considerable advantages such as availability of plants at any time in a year, shorter culturing time, protection of endangered medicinal plants, phenotypic and genotypic homogeneity of plants produced, easier production of challenging species in addition to the benefits ot in vitro propagation methods (Erkoyuncu and Yorgancilar 2016).

Cell concentration is another non-differentiated and non-organized culture method for metabolite. The difference in the culture medium of cell concentration from that of callus culture is that a thickening agent is added to the callus culture medium whereas it is not added in the concentration medium. Therefore, concentration medium is liquid. Callus cultures are used in order to get a good result from cell concentration cultures, which is technically more advantageous. Parts taken from callus culture that has adapted to in vitro medium can adapt to liquid medium more easily than those parts taken from the main plant (Atar and Çölgeçen 2013).

Micro propagation is a production method that also allows vegetative propagation of medicinal and aromatic plants fast and in high quantities. It is defined as obtaining new plants under in vitro conditions from the plant parts that have the potential to form a whole plant (embryo, seed, body, shoot, root, callus, one cell or pollen grain etc.). If the nutrient requirements of plants, growth regulator and culture requirements are known very well, all plant species can be produced using the micro propagation technique. (Erkoyuncu and Yorgancilar 2016).

Hairy root method can be suggested as the most effective method of all the abovementioned ones. Hairy root culture is more advantageous for secondary metabolite production compared to other culture systems because of its various characteristics such a high growth rate and genetic and biochemical stability. Hairy root cultures form model systems for plant metabolism and physiology. Plant cell concentration is one of the culture stages of manufacturing special chemical substances and pharmaceuticals. Hairy roots are also used as a source in transgenic plant regeneration (Atar and Çölgeçen 2013)

Biotechnological intervention makes it possible to remove the time, cost and geopolitical constraints of crop production and overcome the challenging issues such as climate and disease without compromising the sustainability of the nature. Majority of the biotechnology-based production systems include "the production of plant-based therapeutic molecules using in-vitro plant cultures". As regards the reasons of the of plants for therapeutic purposes, we thing that any plant-based metabolite has a significant medicinal value or it act as a precursor to start the medicinal action. Components that provide medicinal effect are usually the products of secondary metabolites and thus they are produced in small quantities as they are not essentially required for plant growth. Besides, production of plants that have medicinal metabolites may take several months or years for the maturation of plants. Moreover, they are vulnerable to environmental and seasonal changes and thus 
cannot strike the supply and demand equilibrium. Due to their complex chemical complexes, their chemical synthesis is boring and complicated. (Dubey et al. 2017)

In vitro plant culture under selective and nutritional conditions is a promising production technique, through which is bioactive compounds are produced using isolated cells and/or organs. This technique is divided into two categories as production based on cell concentration cultures and production based on roots/ hair roots. As regards the comparison of cell concentration culturing method with plant root cultures and hairy root cultures, the former has some limitations such as metabolite production in specialized cells at different development stages and genetic instability of these cells. Features such as high growth rate and low culture cost make hairy root cultures be superior to plant root cultures. Hairy root culture method have distinctive features such as high growth potential, genetic and biochemical binding, low doubling time and etc. Moreover, when optimized for liquid cultures, they can display their final growth and metabolite production capabilities even at large-scale productions. There are research reports and reviews in the literature regarding therapeutic SM production by hairy root culture method (Dubey et al. 2017).

\section{Harry Root Culture Method}

Hairy root is indeed a plant disease. It is caused by Agrobacterium bacteria that are gram-negative bacteria in the family of Rhizobiaceae which lives in the soil. Agrobacterium tumafaciens causes root collar tumours while Agrobacterium rhizogenes leads to hairy root formation. This disease manifests itself as small and excessive enlargements in the parts of trunks and roots that are closer to the soil surface. At early development stages, tumours are more or less globular, white or nude coloured and very soft. At later stages, external tissues become brown or black due to cell death and decay. They transfer their own DNA region to the plant's genome through the genes they carry in both their own genomes and plasmids, which leads to hairy root disease (Hooykaas and Schilperoort 1984).

Hairy root culture has the following advantages: easy to apply, affordable, high genetic transformation rate, stable metabolite yield as the stable settlement of the transferred gene in the genome, fast root growth without need for external auxin use, same and even higher potential to produce secondary metabolites compared to the main plant, allowing genetic manipulations targeted in the metabolic pathway where the synthesis realized. Therefore, it is preferred for the production of several root-driven or non-root driven metabolites in cases when other cell and tissue culture techniques are not appropriate (Erkoyuncu and Yorgancilar 2016).

Low production rate and high production costs are the main reasons why there is failure at industrial scale as regards the production of secondary metabolites. Various strategies have been used to make hairy root culture technology affordable for the production of therapeutic molecules. They include ambient optimization, precursor feeding, elicitation and metabolic engineering. They have been extensively explored at a global scientific platform for not only secondary metabolite production but also better understanding of natural gene transfer and its physiological, molecular and biochemical results.

\subsection{Ambient Optimization}

Hairy root formation is followed by medium optimization. Hairy roots can basically grow in any basal tissue culture medium as underlined in the studies of Murashige and Skoog, Gamborg's B5, Nitsch and Nitsch. Nutritional requirements may vary depending on the plant system and purpose of establishing the roots. Hairy roots of some plant species grow well in a medium enhanced with additional vitamin while those of some other plant species require half and even a quarter of regular growth environment. Furthermore, the amount of both carbohydrate source and nitrogen source and its type play an important role in growth and SM production. Sometimes ambient optimization is needed to assess the relation between food supplement and desired metabolite flow. The presence of a certain nutrient in the medium of hairy root cultures of some plant species is important for not only growth but also accumulation of the desired metabolite (Murthy et al. 2014) (Pudersell et al. 2012). Media are optimized with hairy roots; while they are also considered as a preliminary strategy to optimize metabolite production using hairy root cultures (Sung et al. 2000) . 


\subsection{Elicitation}

Elicits are compounds that stimulate any kind of plant defence. A wider definition of elicits includes exogenous elicitors and compounds released by plants due to the movement of pathogenic substances (pathogen (endogenous elicitors). Plants display a wide range of defence strategies against pathogen attacks. Resistance to pathogens is realized by the existing (founder) and evoked defence systems. Induction defence reactions are triggered after the recognition of a series of chemical factors named 'elicitors'. Indeed, the term elicitor is used for molecules that can induce phytoalexin but it is currently used for compounds that stimulate any kind of plant defence (Angelova et al. 2006).

Elicitation is the induced and/or extended biosynthesis of SMs due to the initiation of a physical, chemical or biological elicitor (information molecule) in a plant system (Namdeo A. 2007). Information molecule activates the inducible defence variables in a plant system and leads to the activation of its various protection mechanisms. The biosynthesis of the same or new SMs in the sstem is induced or extended through such mechanisms. As in robust plants, physical, chemical and biological factors trigger quantitative and qualitative change in the biochemical profile of hairy roots due to the induced enzymatic pathways. Therefore, elicitation is a widely acknowledged strategy applied to increase the production of therapeutic SMs that are preferred to hairy root culture of medicinal plants. Root tissue's response to the elicitor molecule requires a well-defined signal transmission network on cell surface and inside cells. The interaction between signal transducers and regulation of the next SMs' biosynthetic pathway genes is the main reason for the changes in the biochemical profiles of the hairy roots obtained (Goel et al. 2011) .

\subsection{Precursor feeding, Biotransformation and Co-Culture Systems}

Limitation of precursor molecules in the system is one of the main reasons for low SM yield of hairy roots. Addition of metabolic pathway precursors to the medium may induce or improve the deired metabolite synthesis or accumulation. In most of the cases, enzyme machine is available to proceed the desired metabolites but the system cannot achieve optimum or sufficient yield due to the lack of close and remote precursors. To solve this problem, biotransformation of precursors required to obtain the desired metabolite has been explored for several plants (Murthy et al. 2014).

Plant-based pharmaceutical compounds that grow naturally acquire better therapeutic properties due to the changes introduced to their molecular structures. There is an increasing commercial demand for these analogues of natural compounds due to decreased toxicity, sufficient resolution and better pharmacokinetics. Hairy root based biotransformation creates compounds with better therapeutic potential in which any substrate transforms to the analogue of its molecule. It is known that there are remarkable therapeutic compounds produced using the method of enzymatic transformation of medicinal plants' hairy roots and chemical reactions such as hydroxylation, glycosylation, glucosylation, oxidoreduction, hydrogenation and hydrolysis caused by the enzymatic reactions (Srivastava V. 2015) .

\subsection{Metabolic Engineering}

Every biological system has a well-regulated information flow from genes to metabolites. At molecular level, the activated regulatory network causes defined physiological and biochemical changes to keep the system balanced during the initiation of excitatory signals. Due to their proximity to local plants, hairy root cultures are globally used to investigate various aspects of plant behaviour and its regulation at molecular level under variable conditions. Production of therapeutic SMs and their regulation by way of genetic manipulation attract scientists. Metabolic engineering of hairy root based SM pathways can be manipulated through the following ways.

\subsubsection{Engineering of Metobolic Pathway Genes}

Under this method, genetic manipulation directly leads to the desired metabolic shift. The concerned gene may go through early or late /final biosynthesis step but engineering at the late/final steps results in more satisfactory production. Target genes are usually on the rate-limiting step, which is followed by reactions 
catalysed by non-limiting enzymes. Multiple gene engineering is also a common trend. This approach has been used to increase therapeutic molecules in tropane alkaloids (TA) and terpenoid indole alkaloids (TIA) (Moyano et al. 2003).

\subsubsection{Transcription Factor Engineering}

Plant SMs are primarily involved in plant-environment interactions. Such interactions are mediated by a series of gene expression modulations through hormonal signalling followed by transcription factors (TF). The reason why hairy root cultures produce high amount of SMs is because stress-related hormones that regulate TFs are identified and used (Yang et al. 2012).

\subsubsection{Simultaneous Engineering of Metabolic Pathway Genes and Transcription Factors}

Sometimes overexpression of TFs does not result in an increase in distinct metabolites. This is the result of the regulation of multiple metabolic pathways which does not change the overall result significantly ( $\mathrm{Li}$ et al. 2015) .

\subsection{Addition and Expression of a Relevant Gene Isolated from a Different Source}

Under this method, an unwanted molecule can only be produced by transferring a relevant gene segment to the hairy root cells of host plants from a non-plant source. This approach is considered to be a logical action to suppress the activity of unwanted genes related to the concerned property or metabolite. In general, this strategy is used to define the significance of a gene in a biosynthetic pathway. Moreover, in hairy root culture based SM production, the strategy is also used to produce unnatural metabolites or manipulate a metabolic pathway (Runguphan et al. 2009).

\subsection{Changing Chromosome Number}

The purpose of this method is to increase the metabolite production potential by doubling or multiplying the number of basal chromosomes, thereby increasing the overall plant potential. This method may originate from the of conventional breeding which has a high productivity potential in polyploid plants. This superiority also applies to the other properties of the plant including SM production. There is a correlation between Changing Chromosome Number and enhancement of phytopharmaceuticals ( Lavania et al. 2005).

\section{Biotransformation}

All of the above-mentioned secondary metabolite production methods can be collected under the heading of biotransformation. Plants are living organisms and they can consider as a biosynthetic laboratory for each kind of metabolites. The interest in the production of secondary metabolites using there techniques stems from there being commonly of high value but required in relatively small quantities. Biotransformation is also a important technique for production of metabolite. Biotransformation is defined as the conversion of a small part of chemical molecule by means of biological system (Dave et all 2014). Biotransformation explores the unique properties of biocatalysts, namely their stereo-and region-specificity and their ability to carry out reactions at no extreme $\mathrm{pH}$ values and temperatures. Biotransformation may be used to carry out specific conversions of complex substrates using plant, animal or microbial cells or purified enzymes as catalyst (NPTEL).

Biotransformation is an important implementation area for the production of secondary metabolites using plant tissue and cell cultures. It has is a technology with the same synthesis cycle and applied to transform less-beneficial to more-beneficial.

For example, digitoxin and digoxin are isolated from Digitalis lanata, which are the most important ingredients of drugs that regulate heart rhythm. Although digitoxin is more available, digoxin is preferred more commonly for treatment purposes. For that reason, transformation is realized via chemical synthesis (Baydar and Telci 2015). 
Medical and aromatic volatile components can be produced in large quantities by biotransformation techniques. In this review, biotransformation methods have been investigated and it is aimed to get an idea about the possibilities of use of essential oil production techniques. therefore, understanding the importance of the issue will allow new working groups to develop this techniques.

\section{References}

Adams R.P. (2004). Identification of essential oil components by gas, quadrupole spectroscopy. Allured publishing Co, Carol Stream, IL, USA, pp.1-456.

Angelova, Z., Georgiev, S., Roos, W. (2006). Elicitation of plants. Biotechnology Biotechnological Equipment, 20(2), 72-83.

Atar, H., Çölgeçen, H. (2013). Bitki doku kültüründe iridoit glikozitler. Marmara Fen Bilimleri Dergisi,25(3), 115-133.

Babaoğlu, M., Gürel, E., Özcan, S. (2001) Bitki Biyoteknolojisi I. Doku Kültürü ve Uygulamaları. Selçuk Üniversitesi Basımevi, 374.

Baydar, H., Telci, İ. (2015). Tıbbi ve aromatik bitkilerde sslah, tohumluk, tescil ve sertifikasyon. Türktop Dergisi 5(15): 12-21

Bayrak, A. (2006). Gıda Aromaları. Gıda Teknolojisi Derneği Yayın no: 32.497 s., Baran Ofset, Ankara.

Bayram, E., S. Kırıcı, S. Tansı, G. Yılmaz, O. Arabacı, S. Kızıl, İ. Telci (2010). Tıbbi Ve Aromatik Bitkiler.

Ceylan, A. (1983). Tıbbi Bitkiler-II. Ege Üniversitesi Ziraat Fakültesi Yayını No:481, Bornova-İzmir.

Çalikoğlu, E., Kıralan, M., Bayrak, A., (2006). Uçucu Yağ Nedir, Nasıl Üretilir ve Türkiye'deki Durumuna Genel Bir Bakış Türkiye 9. Gıda Kongresi, 24-26.

Çelik, E., Çelik, G.Y. (2007). Bitki uçucu yağlarının antimikrobiyal özellikleri. On-Line Mikrobiyoloji Dergisi, 5(26).

Dave, V., Khirwadkar, P., Dashora, K. (2014). A review on biotransformation. Indian Journal of Research in Pharmacy and Biotechnology, 2(2), 1136.

Dubey, S. K., Pandey, A., Sangwan, R. S. (2017) Current Developments in Biotechnology and Bioengineering. ISBN: 978-0-444-63661-4 pages, Pages 259-282. Elsevier B.V Amsterdam, Netherlands.

Erkoyuncu, M. T., Yorgancılar, M. (2016). Bitki Doku Kültürü Yöntemleri İle Sekonder Metabolitlerin Üretimi. Selçuk Tarım Bilimleri Dergisi, 2(1), 66-76.

Evren M., Tekgüler B., (2011). Uçucu Yağların Antimikrobiyel Özellikleriec Mikrobiyoloji Dergisi , 9(3), 2840.

Gülsoy, S., Merdin, A. (2017). Boylu Ardıç (Juniperus excelsa Bieb.) Türünün Yapraklarında Uçucu Yağ Miktarı ve Bileşenleri. Bilge International Journal of Science and Technology, 1 (2): 119-128.

Goel M.K. ,Mehrotra S. ,Kukreja A.K. (2011). Elicitor-induced cellular and molecular events are responsible for productivity enhancement in hairy root cultures: an insight study, Applied Biochemistry and Biotechnology 165 (5-6) (2011) 1342-1355.

Hooykaas P. J. J., Schilperoort R. A. (1984). The moleculer genetics of crown gall tumorigenesis. In: Scandalios Jg, Caspari EW (eds), Advances in Genetics, Volume 22, Molekuler Genetics of Plants., pp. 209-283.

Kaya, D., Ergönül, PG. (2015). Obtaining methods of volatile oils. GIDA-Journal of Food, 40(5), 303-310.

Lavania, U. C. (2005). Genomic and ploidy manipulation for enhanced production of phytopharmaceuticals." Plant Genetic Resources3.2 (2005): 170-177. 
Linskens, H. F., Jackson, J.F. (1997). Modern Methods of Plant Analysis, Vol. 12: Essential Oils and waxes, Springer, Germany,

Li B., Wang B. ,Li H. , Peng L. , Ru M. , Liang Z. (2016). Establishment of Salvia castanea Diels f. tomentosa Stib. hairy root cultures and the promotion of tanshinone accumulation and gene expression with Ag, methyl jasmonate, and yeast extract elicitation, Protoplasma 253 (1) (2015) 87-100.

Mehrotra, S., Srivastava, V., Rahman, L. U., Kukreja, A. K. (2015). Hairy root biotechnology-indicative timeline to understand missing links and future outlook. Protoplasma, 252(5), 1189-1201.

Moyano E. , Jouhikainen K. , Tammela P., Palazo'n J., Cusido R. M., Pin ol M. T. (2013). Effect of pmt gene overexpression on tropane alkaloid production in transformed root cultures of Datura metel and Hyoscyamus muticus, Journal of Experimental Botany 54 (381) (2003) 203-211.

Murthy, H. N., Lee, E. J., Paek, K. Y. (2014). Production of secondary metabolites from cell and organ cultures: strategies and approaches for biomass improvement and metabolite accumulation. Plant Cell, Tissue and Organ Culture (PCTOC), 118(1), 1-16.

Namdeo, A. G. (2007). Plant cell elicitation for production of secondary metabolites: a review." Pharmacogn Rev 1.1 69-79.

NPTEL Courses, IIT Guwahati Module 4 : Application of Cell Culture Systems in Metabolic Engineering Lecture 38 : Biotransformation National Programme on Technology Enhanced Learning. Retrieved at 03-OCTOBER-2012

Özkaynak, E., Samancı, B. (2005). Mikroçoğaltımda Alıştırma. Selçuk Tarım Ve Gıda Bilimleri Dergisi, 19(36), 28-36.

Pudersell, Katrin. (2012). Inorganic ions in the medium modify tropane alkaloids and riboflavin output in Hyoscyamus niger root cultures. Pharmacognosy magazine 8.29 (2012): 73.

Runguphan, Weerawat, Justin J. Maresh, Sarah E. O'Connor. (2009). Silencing of tryptamine biosynthesis for production of nonnatural alkaloids in plant culture. Proceedings of the National Academy of Sciences 106.33 (2009): 13673-13678.

Sung L.S. , Huang S.Y. (2000). Medium optimization of transformed root cultures of Stizolobium hassjoo producing L-DOPA with response surface methodology, Biotechnology Progress 16 (6) (2000) 1135 1140 .

Yang C.Q., Fang X., Wu X.M., Mao Y.B., Wang L.J., Chen X.Y.(2012) Transcriptional regulation of plant secondary metabolism, Journal of Integrative Plant Biology 54 (2012) 703-712.

Yaylı, N. (2013). Uçucu Yağlar ve Tıbbi Kullanımları. 1. İlaç Kimyası, Üretimi, Teknolojiisi, Standardizasyonu Kongresi, Kimyagerler Derneği, 29-31 Mart 2013, Antalya 